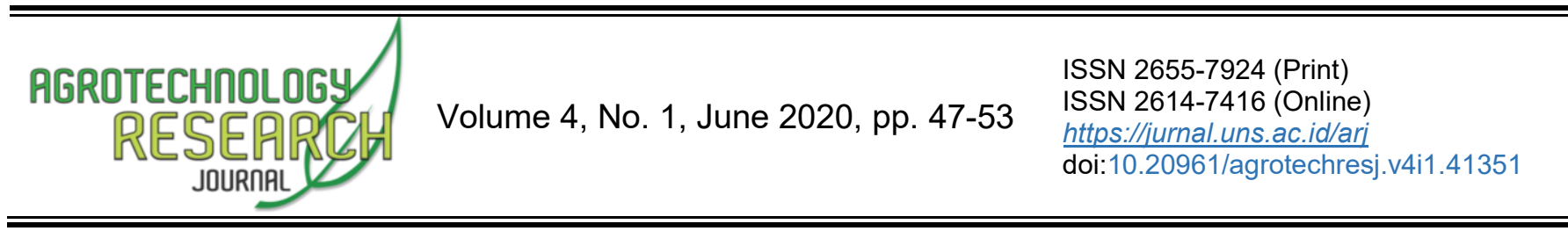

\title{
Antagonisme Fungi Endofit Daun Jarak Pagar (Jatropha curcas) terhadap Fusarium oxysporum C2 Penyebab Busuk Umbi pada Bawang Merah in Vitro
}

\author{
Fauziyyah Nahdah ${ }^{1}$, Noorkomala Sari ${ }^{\star}$, Akhmad Rizali ${ }^{3}$, Rabiatul Wahdah ${ }^{4}$ \\ ${ }^{1-4}$ Department of Agroecotechnology, Faculty of Agriculture, Universitas Lambung Mangkurat, Banjarmasin, Indonesia
}

Received 26 April 2020; Accepted 16 June 2020; Published 25 Juni 2020

\begin{abstract}
Basal plate rot is a major disease on shallot caused by Fusarium oxysporum. Endophytic fungi is promising to use as antagonist agent to the pathogen. Endophyte is microbes that are living in plant cells and have an asymptomatic characteristic. Nowadays, fungal endophyte is believed to produce antimicrobial substances similar with their plant host's natural product. Jatropha curcas is one of the plants containing secondary metabolites that have antifungal activities. The research aimed to study the ability of endophyte from Jatropha curcas to inhibit the growth of Fusarium oxysporum. The dual culture method was used in this research and the data were analyzed by SPSS software. This antagonism test was conducted by 9 isolates endophyte and each plate consisted of 3 replicates. The result revealed endophyte fungal obtaining 9 isolates with the radial growth of $4,5 \mathrm{~cm} / 2$ days. Endophytes of Jatropha curcas $\mathrm{L}$. were able to inhibit the growth of Fusarium oxysporum C2. The percentage of inhibition of Fusarium oxysporum causing of root blight diseases was controlled by up $38.27-74.48 \%$. The highest percentage of inhibition is gained by B4b and the lowest of it is A2b. Our observations showed that each endophyte has a consistent linear trend. B4b still leaded as the highest strength to inhibit the growth of pathogen on the monitoring of 3,5 , and 7 days. Moreover, the ability of fungi endophyte from Jatropha curcas as antagonist agent to Fusarium oxysporum needs to be further examined by the in vivo method.
\end{abstract}

Keywords: Biological control; Percentage of inhibition; Root blight; Inhibition mechanism

Cite This As (CSE Style): Nahdah F, Sari N, Rizali A, Wahdah, R. 2020. Antagonisme Fungi Endofit Daun Jarak Pagar (Jatropha curcas) terhadap Fusarium oxysporum C2 Penyebab Busuk Umbi pada Bawang Merah in Vitro. Agrotech Res J 4(1): 47-53. http://doi.org/10.20961/agrotechresj.v4i1.41351

\section{PENDAHULUAN}

Bawang merah merupakan komoditas yang telah lama dibudidayakan secara intensif oleh petani karena pemanfaatannya sebagai penyedap makanan, bumbu rempah dan obat tradisional. Produksi bawang merah nasional cukup memadai untuk menyuplai kebutuhan konsumsi dalam negeri, namun hasil produksi berfluktuasi di beberapa waktu terutama saat kondisi iklim tidak normal (Suwandi 2014). Salah satu penyakit penting pada bawang merah adalah busuk umbi yang disebabkan oleh Fusarium oxysporum. Busuk umbi atau yang lebih dikenal dengan moler dapat menyebabkan kerusakan langsung serta penurunan produksi hingga 50\% (Zulaika 2014). Baswarsiati dan Korlina (2000) menyatakan kerusakan akibat moler pada umur 42 hari setelah tanam (HST) mencapai $75 \%$ dan akan terus bertambah jika tidak dilakukan pengendalian.

Pengendalian penyakit moler umumnya dilakukan dengan penggunaan pestisida. Penggunaan pestisida secara terus-menerus dan berlebihan dapat

\section{*Corresponding Authors:}

${ }^{1} E$-mail: noorkomala.sari@ulm.ac.id menimbulkan beberapa dampak negatif seperti resurjensi, resistensi hama dan patogen serta kematian musuh alami (Adriyani 2006). Usaha pengendalian hama dan patogen saat ini diarahkan pada pemanfaatan musuh-musuh alami atau yang lebih dikenal dengan pengendalian secara hayati. Pengendalian penyakit menggunakan agen hayati diyakini mampu mengendalikan penyakit tanpa menyebabkan dampak negatif terhadap lingkungan. Salah satu upaya pengendalian secara hayati adalah dengan menggunakan endofit.

Endofit adalah mikroorganisme yang hidup di dalam jaringan tanaman sehat tanpa menunjukkan gejala penyakit (Rodriguez et al. 2009; Faeth dan Fagan 2002). Studi melaporkan bahwa endofit memiliki potensi hubungan simbiosis mutualisme dengan tanaman inangnya, dimana endofit mendapatkan fotosintat dari hasil metabolisme tanaman inang dan tanaman inang akan mendapatkan senyawa metabolit sekunder yang membantu dalam meningkatkan ketahanan tanaman terhadap serangan patogen (Taechowisan et al. 2003).

Endofit dilaporkan oleh beberapa studi memiliki kemampuan menghasilkan senyawa fitokimia yang sama dengan tanaman inangnya selama proses evolusinya dalam bersimbiosis (Rodriguez et al. 2009; Joseph dan Priya 2011; Schulz et al. 2002). Beberapa 
senyawa ini berpotensi dalam hal meningkatkan ketahanan tanaman terhadap serangan patogen dengan mendukung tanaman menghasilkan senyawa metabolit sekunder seperti ergot alkaloid dan indole diterpenoid (Lane et al. 2000). Kemampuan endofit sebagai sumber penghasil metabolit sekunder yang sama dengan tanaman inangnya menjadikannya sebagai alternatif sumber senyawa bioaktif (Strobel dan Daisy 2003).

Selain kemampuannya dalam menghasilkan senyawa metabolit sekunder fungi endofit juga mampu menghasilkan beberapa enzim litik dalam mendegradasi dinding sel patogen; mikotoksin; dan antibiotik dalam menekan pertumbuhan patogen (Gao et al. 2010). Beberapa kemampuan tersebut menjadikan endofit sebagai kandidat antagonis terhadap fungi patogen dalam mengendalikan perkembangan penyakit tanaman. Pada tanaman inangnya, fungi endofit sebagai salah satu mikroba menguntungkan yang berasosiasi dengan tanaman inangnya terlibat dalam mengaktifkan respon metabolisme inang pada sistem ketahanan terinduksi atau Induced Systemic Resistance (ISR) yang difasilitasi oleh senyawa regulator yaitu etilen dan asam jasmonat (Pieterse et al. 2014).

Beberapa penelitian terdahulu menggunakan endofit sebagai agen antagonis terhadap patogen (Istikorini 2008; Noverita dan Sinaga 2009; Xiao et al. 2013) dan sifat antagonis ini ditunjukkan dengan nilai persen kejadian penyakit yang lebih rendah pada tanaman perlakuan. (Zulaika 2014) melaporkan kejadian penyakit busuk umbi pada bawang merah yang telah direndam dengan endofit yang berasal dari tanaman bawang merah sehat menunjukkan nilai kejadian penyakit yang lebih rendah dibandingkan dengan kontrol.

Pada penelitian ini dilakukan uji potensi kemampuan endofit yang diisolasi dari daun jarak pagar karena sifat farmakologi tanaman jarak pagar. Daun jarak pagar (Jatropha curcas L.) telah digunakan masyarakat sebagai obat malaria, demam, penghilang rasa nyeri atau analgesik, dan pembeku atau penstabil darah (Nasution et al. 2019). Jarak pagar memiliki potensi dalam pengembangan produk obat-obatan pertanian serta industri kimia karena mengandung senyawasenyawa bioaktif yang bersifat antimikroba dan antioksidan (Windarwati 2011). Daun jarak pagar mengandung senyawa metabolit sekunder alkaloid, steroid, dan saponin (Nasution et al. 2019) dan penelitian sebelumnya oleh (Rante et al. 2013) bahwa pada akar, kulit batang, biji, dan daun jarak pagar terdapat senyawa alkaloid, flavonoid, saponin, dan terpenoid.

Dilatarbelakangi oleh kemampuan endofit yang menghasilkan senyawa antimikroba yang sama dengan inangnya (Higginbotham et al. 2013; Faeth dan Fagan 2002) pada penelitian ini dilakukan uji potensi endofit daun jarak pagar sebagai agen antagonis terhadap Fusarium oxysporum penyebab penyakit moler pada bawang merah secara in vitro.

\section{BAHAN DAN METODE}

Penelitian dilaksanakan pada bulan Juni hingga Juli 2018 di Laboratorium. Penelitian ini menggunakan metode eksplorasi (isolasi fungi endofit dari daun jarak pagar sehat) dan observasi (uji daya hambat endofit terhadap F. oxysporum). Tahapan penelitian terdiri dari isolasi endofit dari daun jarak pagar, pemurnian (purifikasi) serta pengukuran pertumbuhan miselia isolat fungi endofit dan F.oxysporum C2 dan uji daya hambat dengan metode dual culture. Daun jarak pagar yang digunakan pada penelitian ini berasal dari koleksi tanaman di lingkungan Fakultas Pertanian Universitas Lambung Mangkurat sedangkan patogen yang digunakan adalah $\mathrm{F}$. oxysporum kode isolat $\mathrm{C} 2$ yang diisolasi dari Desa Ujung Batu Kabupaten Tanah Laut, Kalimantan Selatan.

Isolasi fungi endofit dilakukan dengan memotong daun jarak pagar menjadi bagian kecil berukuran $0,5 \times$ $0,5 \mathrm{~cm}$ menggunakan pinset lalu disterilisasi menggunakan sodium hipoklorit $1 \%$ selama 2 menit dan etanol $70 \%$ selama 30 detik dan dibilas dengan Aquades steril sebanyak tiga kali kemudian dikeringkan dengan kertas saring. Potongan daun tersebut dimasukkan ke dalam media PDA. Pemurnian (purifikasi) dilakukan dengan menumbuhkan masing-masing isolat endofit ke dalam cawan petri berisi media PDA baru. Pengukuran pertumbuhan miselia dilakukan dengan mengukur diameter koloni endofit dan $F$. oxysporum C2 menggunakan penggaris pada hari ke-3 5, dan $7 \mathrm{HSI}$.

Metode dual culture dilakukan dengan menumbuhkan patogen F. oxysporum dan fungi endofit (yang masing-masing berumur $7 \mathrm{HSI}$ ) ke dalam satu cawan petri berdiameter $9 \mathrm{~cm}$ yang berisi media PDA. Nilai hambat diukur melalui nilai selisih jarak pertumbuhan patogen pada cawan kontrol (single culture) dengan jarak pertumbuhan patogen pada cawan perlakuan (Malleswari 2014; Begum et al. 2008). Perhitungan uji daya hambat dual culture mengikuti metode yang dikenalkan oleh (Skidmore dan Dickinson 1973).

$$
\text { Daya hambat }(\%)=\frac{R_{1}-R_{2}}{R_{1}} \times 100
$$

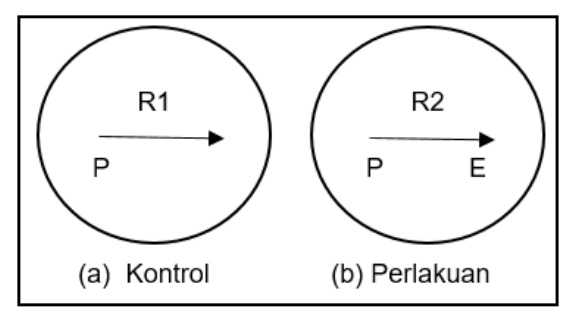

Keterangan: R1 = jarak tumbuh patogen pada cawan kontrol (patogen-agar plug), R2= jarak tumbuh patogen pada cawan perlakuan (patogen-endofit)

\section{Gambar 1. llustrasi metode dual culture}

Rancangan percobaan yang digunakan pada penelitian adalah rancangan acak lengkap (RAL) dengan 10 perlakuan dan diulang sebanyak 3 kali. Data yang didapat dianalisis menggunakan program SPSS. Variabel nilai daya hambat (\%) dianalisis dengan Levene's test. Apabila hasil ragam berbeda nyata akan dilakukan dengan uji post-hoc, Duncan's Multiple Range Test (DMRT). Peubah yang diamati adalah pertumbuhan miselia F.oxysporum C2 dan endofit yang berhasil diisolasi dari daun jarak pagar pada hari ke-3, 5, dan 7 hari setelah inokulasi (HSI) serta daya hambat pada metode dual culture antara isolat endofit dan $F$. oxysporum C2 pada ke-3, 5, dan $7 \mathrm{HSI}$. 


\section{HASIL DAN PEMBAHASAN}

\section{Pertumbuhan miselia isolat dan Fusarium} oxysporum $\mathrm{C2}$

Pertumbuhan miselia dilakukan dengan mengukur diameter koloni dari isolat fungi endofit dan F.oxysporum C2 pada hari ke-3, 5, dan $7 \mathrm{HSI}$. Gambar 2 diketahui diameter pertumbuhan koloni isolat fungi endofit daun jarak pagar yang terdiri atas 9 isolat yaitu: $A 1 ; A 2 a ; A 2 b$; A4b; B3; B4b; C1a; D3; dan D4b serta patogen F.oxysporum $\mathrm{C} 2$ pada masing-masing kultur murni. Pada pengamatan hari ke-7 nilai diameter koloni A1, A2b, A4b, B3, B4b, C1a, dan D3 lebih tinggi dibandingkan dengan $F$. oxysporum $\mathrm{C} 2$, berbeda pada A2a dan D4b yang memiliki nilai diameter koloni lebih rendah dibandingkan F. oxysporum $\mathrm{C} 2$. Shehata and $\mathrm{El}$ Borollosy (2008) menyatakan bahwa salah satu ciri mikroba antagonis ditandai dengan pertumbuhan miselia yang lebih cepat dibandingkan dengan patogen sehingga beberapa isolat daun jarak pagar memiliki potensi sebagai agen antagonis terhadap F.oxysporum $\mathrm{C} 2$ dengan mengkonfirmasi daya hambatnya dengan metode dual culture.

Daya hambat isolat endofit daun jarak pagar terhadap Fusarium oxysporum secara in vitro

Berdasarkan hasil analisis ragam pada Gambar 3 diketahui variabel nilai persen hambat isolat endofit berbeda-beda (beragam) terhadap F. oxysporum. Nilai persen hambat endofit daun jarak terhadap $F$. oxysporum berkisar $38-75 \%$. Hasil persentase hambat fungi endofit tertinggi adalah perlakuan isolat $\mathrm{B} 4 \mathrm{~b}$ $74,48 \%$ sedangkan hasil persentase daya hambat terendah ditunjukkan oleh A2b yaitu sebesar $38,27 \%$ dan persentase daya hambat sedang $(42,99-48,54 \%)$ diperoleh isolat A1; A2a; A4b; B3; D3; D4b; dan C1a. Kemampuan antagonis suatu agensia hayati diukur dengan nilai persentase hambat agensia tersebut, sehingga terjadinya persen hambat menunjukkan bahwa kehadiran fungi endofit isolat daun jarak mampu menghambat pertumbuhan $F$. oxysporum $\mathrm{C} 2$, dimana nilai jarak pertumbuhan $F$. oxysporum $C 2$ pada cawan kontrol (single culture) lebih tinggi dibandingkan dengan nilai jarak pertumbuhan $F$. oxysporum $\mathrm{C} 2$ pada cawan perlakuan.

Perbedaan persentase hambatan dari beberapa endofit menurut (Vinale et al. 2009) dapat disebabkan oleh perbedaan produksi senyawa metabolit sekunder yang dikeluarkan oleh jenis endofitnya. Lebih jauh, faktor-faktor lain yang mempengaruhi produksi metabolit sekunder adalah keseimbangan biosintesis dan biotransformasi, kehadiran jamur lain dan konsentrasi senyawa antibiotik.

Dominasi ruang yang terjadi pada $B 4 b$ selaras dengan kecepatan tumbuh B4b pada saat pengukuran pertumbuhan miselia yang menunjukkan diameter koloni yang lebih tinggi dibandingkan isolat endofit lainnya. Kemampuan menghambat patogen oleh isolat $\mathrm{B} 4 \mathrm{~b}$ diduga karena kemampuannya memperebutkan ruang dan nutrisi sehingga mampu tumbuh dengan cepat dan menghambat pertumbuhan patogen $F$. oxysporum $\mathrm{C} 2$. Faktor ruang tumbuh menjadi salah satu faktor penting yang memengaruhi kerja endofit, menurut Kloeppe et al. (1999) endofit mencegah perkembangan penyakit dengan mekanisme kompetisi ruang dan nutrisi, semakin cepat pertumbuhan agen antagonis mengakibatkan pertumbuhan patogen akan terdesak serta tidak mendapatkan ruang tumbuh dan tidak dapat berkembang. Berbeda dengan endofit $A 2 b$ dimana menunjukkan persentase hambat yang relatif rendah dibandingkan perlakuan lainnya. Hal ini berbeda dengan nilai pertumbuhan isolat $\mathrm{A} 2 \mathrm{~b}$ saat dikultur murni yang menunjukkan pertumbuhan miselia yang tinggi. Rendahnya persentase hambatan pada endofit pada saat dikulturkan dengan metode dual culture dapat dikarenakan kemampuan $F$. oxysporum, menghasilkan toksin sehingga pertumbuhan endofit terhambat. Dilaporkan oleh Fusarium spp. Mampu menghasilkan mikotoksin utama yaitu moniliformin, fumonisin, zearalenone, dan beauvericin (Azliza et al. 2014).

\section{$\square$ Hari ke-3 $\square$ Hari ke-5 $\quad$ Hari ke-7}

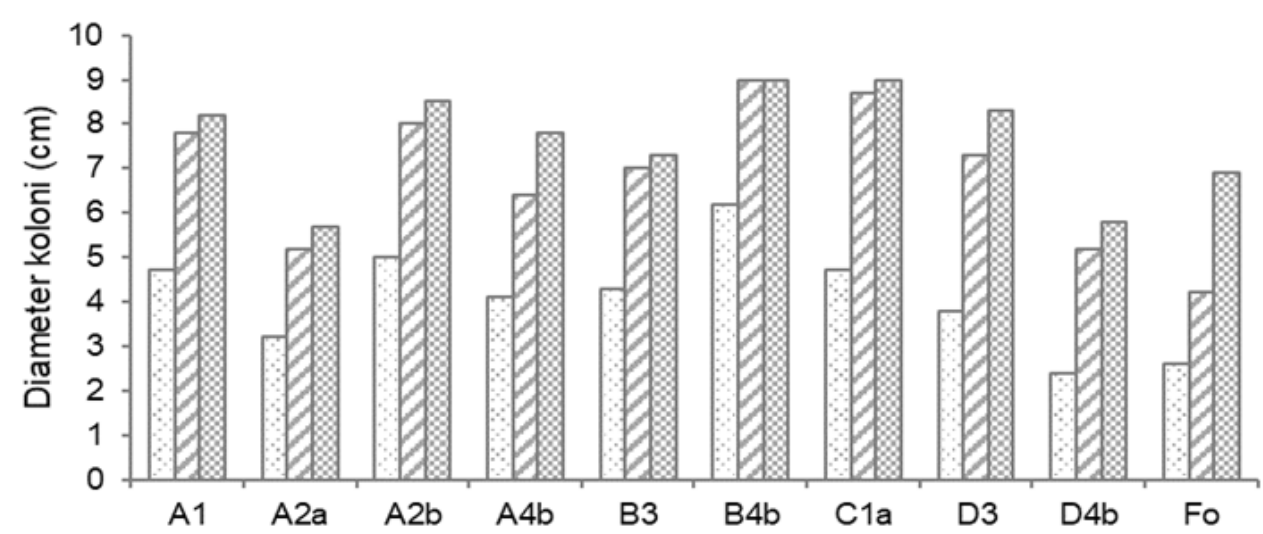

Keterangan: Isolat endofit daun jarak pagar: A1; A2a; A2b; A4b; B3; B4b; C1; D3; dan D4b; Isolat patogen Fusarium oxysporum C2: Fo

Gambar 2. Pertumbuhan miselia isolat endofit daun jarak pagar (Jatropha curcas L.) dan F. oxysporum C2 pada hari ke-3, 5 , dan 7 berdasarkan pengukuran diameter koloni (radial growth colony) 


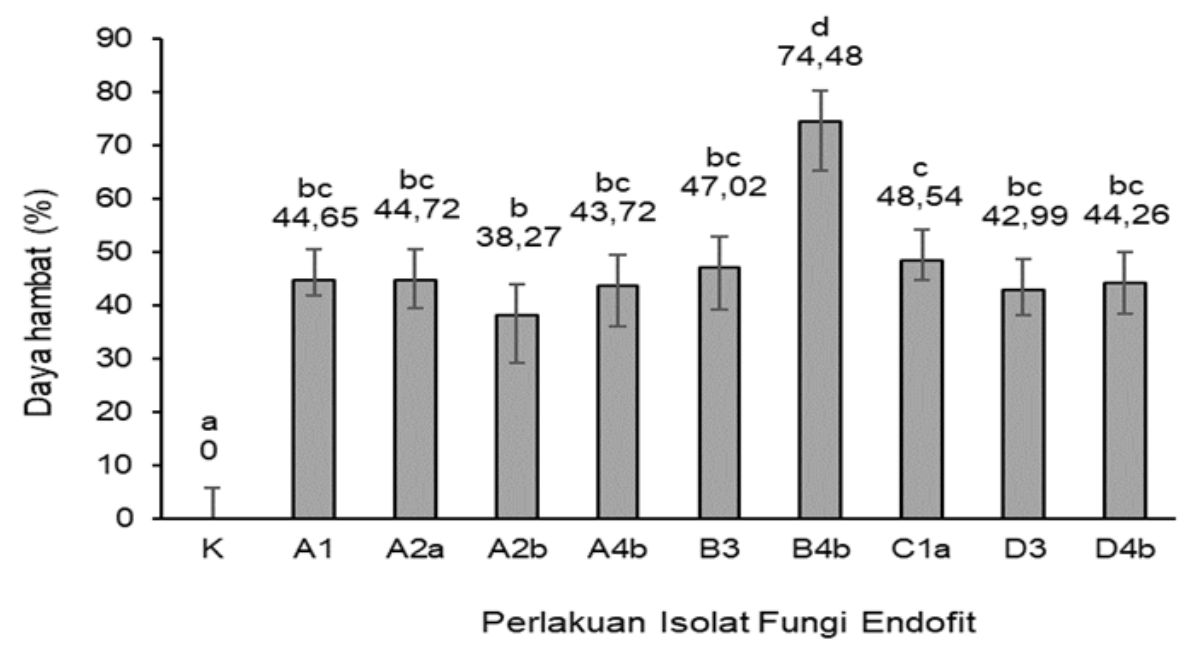

Keterangan: angka yang diikuti huruf sama tidak beda nyata pada uji jarak berganda Duncan's $5 \%$

Gambar 3. Persentase hambat fungi endofit daun Jarak Pagar (Jatropha curcas) terhadap F. oxysporum C2

Pada Gambar 4 ditunjukkan kurva persen penghambatan masing-masing isolat endofit daun jarak pagar pada hari kultur ke-3,5, dan $7 \mathrm{HSI}$. Hal ini menunjukkan peningkatan kekuatan hambat tiap harinya, dimana B4b pada hari ke-3 hingga ke-7 tetap sebagai endofit yang memiliki nilai persen hambat tertinggi, begitu juga dengan endofit $\mathrm{A} 2 \mathrm{~b}$ masih dengan nilai persen hambat terendah di hari ke-3 sampai ke-7, begitu juga dengan isolat lainnya menunjukkan peningkatan persen hambat. Hal ini menunjukkan isolat endofit daun jarak pagar memiliki kekuatan daya hambat yang konsisten selama masa observasi, kemampuan endofit yang dominan dalam memanfaatkan ruang dan nutrisi menunjukkan bahwa endofit daun jarak pagar berkompetisi tumbuh lebih unggul dan bersifat antagonis dengan F.oxysporum.

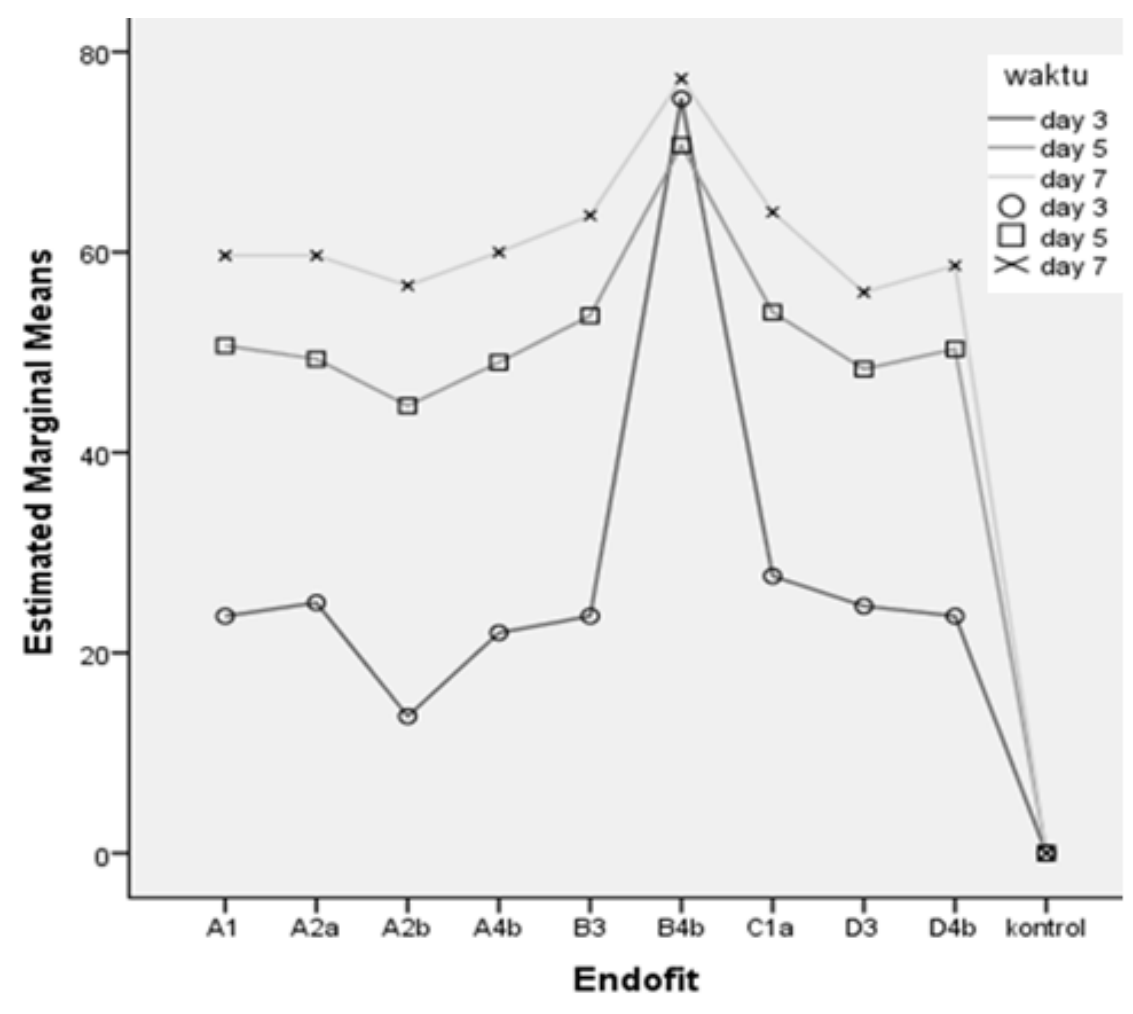

Gambar 4.Perbandingan daya hambat endofit daun Jarak Pagar terhadap Fusarium 
Fungi antagonis memiliki mekanisme hambat yang beragam dan menunjukkan pola kinerja yang juga berbeda terhadap jenis patogen tersebut. Mekanisme interaksi yang terjadi antara patogen dan endofit secara in vitro didasarkan pada empat kriteria yaitu mutually intermingling growth, overgrowth by antagonism, mutual slight inhibition dan mutual inhibition at a distance (Skidmore dan Dickinson 1976). Interaksi hifa antara endofit dengan patogen pada metode dual culture ditunjukkan pada Gambar 5 dimana mekanisme overgrowth by antagonism ditunjukkan pada endofit B4b dan $\mathrm{A} 2 \mathrm{~b}$ karena koloni endofit tersebut tumbuh menutupi maupun tumbuh mengelilingi patogen. Endofit $A 1, A 2 a$, A4b, B3, C1, dan D3 menunjukkan mekanisme mutual slight inhibition dimana endofit dan patogen tumbuh saling mendekati hingga hampir betemu dititik tengah.

Endofit D4b menunjukkan mekanisme mutually intermingling growth dimana endofit dan patogen tumbuh saling tumpang tindih. Endofit B4b mampu tumbuh lebih cepat dibandingkan koloni $F$. oxysporum sehingga menutupi koloni patogen, selain itu B4b juga mampu mendominasi ruang lebih cepat dibandingkan endofit lainnya. Endofit A4b, B3 dan C1 menunjukkan kemampuan mendominasi ruang lebih rendah jika dibandingkan dengan endofit B4b, namun ketiga endofit ini menunjukkan penghambatan pertumbuhan patogen dengan perubahan warna pada daerah kontak.

Pada Gambar 5 ditunjukkan perubahan warna pada titik temu antara $F$. oxysporum $\mathrm{C} 2$ dengan endofit A4b, B3 dan C1. Endofit memiliki mekanisme mikoparasitisme yaitu melekatkan hifanya pada patogen kemudian mensekresikan enzim yang aktif mendegradasi sel (Harman et al. 2004) yang mengakibatkan perubahan warna pada titik temu. Aktifitas enzim tersebut mengakibatkan dinding sel pada hifa F. oxysporum C2 mengalami kerusakan dan perubahan warna. Endofit B3 dan D3 tumbuh diatas miselia F. oxysporum C2. Hifa fungi endofit yang tumbuh diatas permukaan hifa patogen termasuk mekanisme penghambatan dengan memanfaatkan niche atau hiperpredasi (Gao et al. 2010).

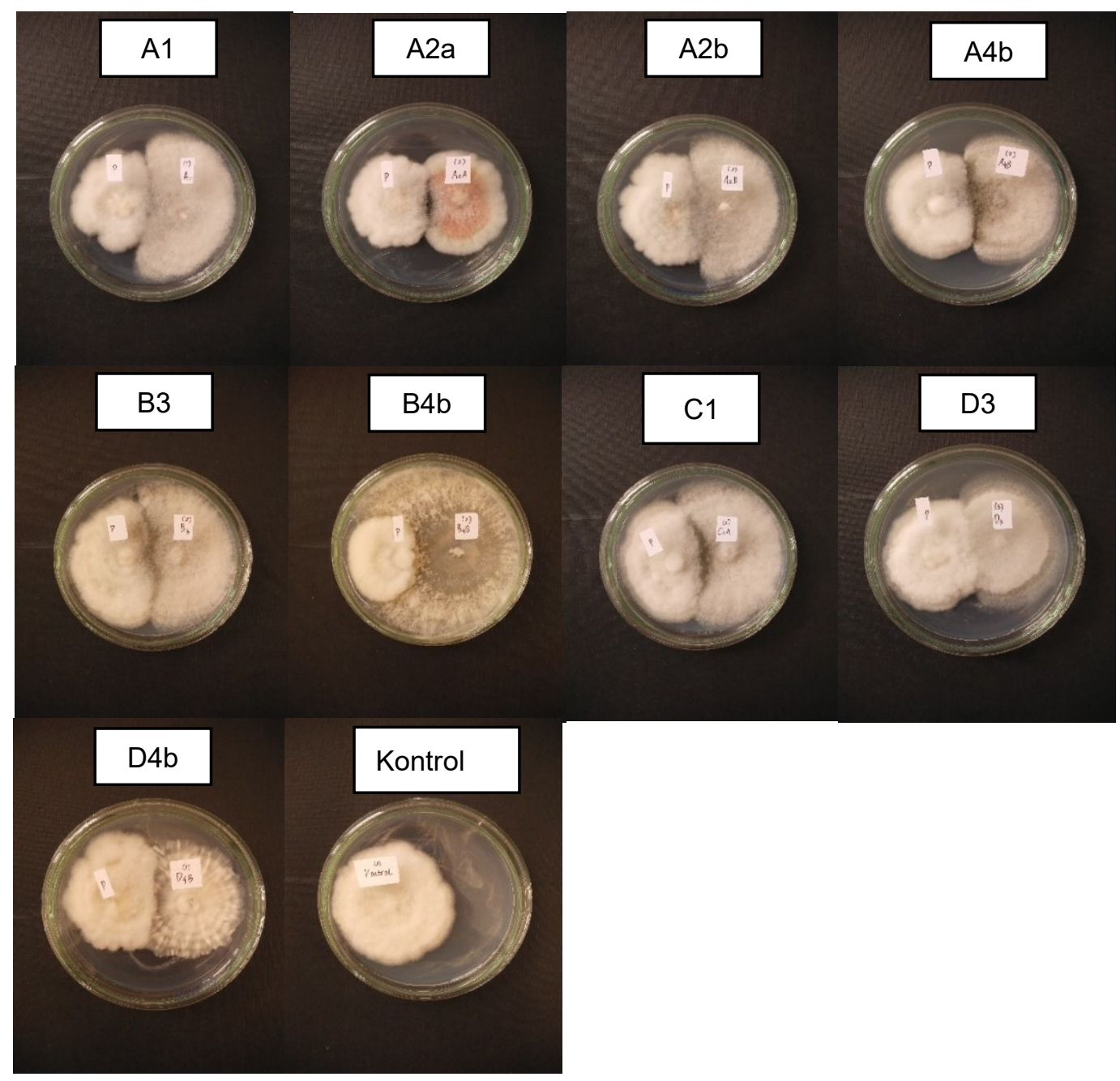

Keterangan: Cawan perlakuan : Fusarium oxysporum $\mathrm{C} 2$ dengan masing-masing fungi endofit isolat daun jarak pagar A1; A2a; A2b; A4b; B3; B4b; C1; D3; dan D4b; Cawan kontrol : Fusarium oxysporum C2 dengan agar plug

Gambar 5. Metode dual culture fungi endofit daun Jarak Pagar (Jatropha curcas L.) terhadap F. oxysporum C2 


\section{KESIMPULAN DAN SARAN}

Isolat endofit yang berasal dari daun Jarak Pagar menunjukkan aktivitas antagonisme terhadap patogen F.oxysporum C2 secara in vitro. Terdapat sembilan isolat fungi endofit yang menunjukkan nilai persen hambat pada pertumbuhan $F$. oxysporum $C 2$ yaitu: isolat $A 2 b$ dengan daya hambat rendah; isolat $B 4 b$ dengan daya hambat kuat; dan tujuh isolat lainnya $A 1 ; A 2 a ; A 4 b$; B3; C1a; D3; dan D4b dengan daya hambat sedang. Perbedaan kekuatan hambatan dari fungi endofit disebabkan oleh perbedaan produksi senyawa metabolit sekunder yang dikeluarkan oleh masing-masing endofit, kemampuan interaksi dengan agen/ jamur lain dan konsentrasi senyawa mikotoksin atau antibiotik yang diproduksi. Kekuatan daya hambat ini untuk tiap isolat fungi endofit menunjukkan nilai yang konsisten, dimana B4b pada hari ke-3 hingga ke-7 tetap sebagai endofit yang memiliki nilai persen hambat tertinggi dan $A 2 b$ masih dengan nilai persen hambat terendah di hari ke-3 sampai ke-7.

Daya hambat isolat fungi endofit dari daun jarak pagar sebagai agen antagonis terhadap F.oxysporum C2 secara in vitro merupakan skrining awal dalam menguji potensinya, masih diperlukan penelitian lebih lanjut dalam menguji daya hambatnya secara in vivo mengingat interaksi endofit-inang bisa terjadi secara host-spesific.

\section{DAFTAR PUSTAKA}

Adriyani R. 2006. Usaha Pengendalian Pencemaran Lingkungan Akibat Penggunaan Pestisida Pertanian. J Kesehat Lingkung 3(1)

Azliza IN, Hafizi R, Nurhazrati M, Salleh B. 2014. Production of major mycotoxins by Fusarium species isolated from wild grasses in Peninsular Malaysia. Sains Malays. 43:89-94.

Baswarsiati LR, Korlina E. 2000. Review Pengkajian Usahatani Bawang Merah di Lahan Sawah. In: Eds Soetjipto P.H et al, editor. Hasil Penelitian/Pengkajian Teknologi Pertanian Mendukung Ketahanan Pangan Berwawasan Agribisnis. Bogor: Pusat Penelitian dan Pengembangan Sosial Ekonomi Pertanian. p. 392402.

Begum MM, Sariah M, Abidin ZMA, Puteh AB, Rahman MA. 2008. Antagonistic potential of selected fungal and bacterial biocontrol agents against Colletotrichum truncatum of soybean seeds. Pertanica J Trop Agric Sci. 31:45-53.

Faeth SH, Fagan WF. 2002. Fungal endophytes: common host plant symbionts but uncommon mutualists. Integr Comp Biol. 42(2):360-368.

Gao F-K, Dai C-C, Liu X-Z. 2010. Mechanisms of fungal endophytes in plant protection against pathogens. African J Microbiol Res. 4(13):1346-1351.

Harman GE, Howell CR, Viterbo A, Chet I, Lorito M. 2004. Trichoderma species - opportunistic, avirulent plant symbionts. Nat Rev Microbiol. 2(1):43-56. doi:10.1038/nrmicro797.
Higginbotham SJ, Arnold AE, Ibañez A, Spadafora C, Coley PD, Kursar TA. 2013. Bioactivity of fungal endophytes as a function of endophyte taxonomy and the taxonomy and distribution of their host plants. PLoS One. 8(9).

Istikorini Y. 2008. Potensi cendawan endofit untuk mengendalikan penyakit antraknosa pada cabai (Capsicum annum L.)[disertasi]. Bogor Inst Pertan Bogor.

Joseph B, Priya RM. 2011. Bioactive Compounds from Endophytes and their Potential in Pharmaceutical Effect: A Review. Am J Biochem Mol Biol. 1(3):291309.

Kloeppe JW, Rodríguez-Kábana R, Zehnder AW, Murphy JF, Sikora E, Fernández C. 1999. Plant rootbacterial interactions in biological control of soilborne diseases and potential extension to systemic and foliar diseases. Australas Plant Pathol. 28(1):21-26. doi:10.1071/AP99003.

Lane GA, Christensen MJ, Miles CO. 2000. Coevolution of fungal endophytes with grasses: the significance of secondary metabolites. Microb endophytes. 2000:341-388.

Malleswari D. 2014. In vitro antagonistic activity of diverse bacterial isolates against Macrophomina phaseolina (Tassi) Goid. Int J Curr Microbiol Appl Sci. 3(5):755-763.

Nasution ADM, Amna U, Halimatussakdiah H. 2019. Skrining Fitokimia Daun Jarak Pagar (Jatropha curcas L.) dari Kota Langsa. Quim J Kim Sains dan Terap. 1(1):11-15.

Noverita FD, Sinaga E. 2009. Isolasi dan uji aktivitas antibakteri jamur endofit dari daun dan rimpang Zingiber ottensii Val. J Farm Indones. 4(4):171-176.

Pieterse CMJ, Zamioudis C, Berendsen RL, Weller DM, Van Wees SCM, Bakker PAHM. 2014. Induced systemic resistance by beneficial microbes. Annu Rev Phytopathol. 52:347-375.

Rante H, Taebe B, Intan S. 2013. Isolasi Fungi Endofit Penghasil Senyawa Antimikroba dari Daun Cabai Katokkon (Capsicum annuum L. var. chinensis) dan Profil KLT Bioautografi. Maj Farm dan Farmakol. 17(2):39-45.

Rodriguez RJ, White Jr JF, Arnold AE, Redman RS. 2009. Fungal endophytes: diversity and functional roles. New Phytol. 182(2):314-330. doi:10.1111/j.1469-8137.2009.02773.x.

Schulz B, Boyle C, Draeger S, Römmert A-K, Krohn K. 2002. Endophytic fungi: a source of novel biologically active secondary metabolites. Mycol Res. 106(9):996-1004.

Shehata SF, El-Borollosy AM. 2008. Induction of resistance against Zucchini yellow mosaic potyvirus and growth enhancement of squash plants using some plant growth-promoting Rhizobacteria. Aust J basic Appl Sci. 2(2):174-182. 
Skidmore AM, Dickinson CH. 1973. Effect of phylloplane fungi on the senescence of excised barley leaves. Trans Br Mycol Soc. 60(1):107-116.

Skidmore AM, Dickinson CH. 1976. Colony interactions and hyphal interference between Septoria nodorum and phylloplane fungi. Trans Br Mycol Soc. 66(1):5764. doi:10.1016/s0007-1536(76)80092-7.

Strobel G, Daisy B. 2003. Bioprospecting for microbial endophytes and their natural products. Microbiol Mol Biol Rev. 67(4):491-502. doi:10.1128/mmbr.67.4.491-502.2003.

Suwandi. 2014. Budidaya Tanaman Bawang Merah di Luar Musim. Jakarta: IAARD Press.

Taechowisan T, Peberdy JF, Lumyong S. 2003. Isolation of endophytic actinomycetes from selected plants and their antifungal activity. World J Microbiol Biotechnol. 19(4):381-385. doi:10.1023/A:1023901107182.
Vinale F, Ghisalberti EL, Sivasithamparam K, Marra R, Ritieni A, Ferracane R, Woo S, Lorito M. 2009. Factors affecting the production of Trichoderma harzianum secondary metabolites during the interaction with different plant pathogens. Lett Appl Microbiol. 48(6):705-711.

Windarwati S. 2011. Pemanfaatan Fraksi Aktif Ekstrak Tanaman Jarak Pagar (Jatropha curcas Linn.) sebagai Zat Antimikroba dan Antioksidan dalam Sediaan Kosmetik. Institut Pertanian Bogor.

Xiao Y, Li H-X, Li C, Wang J-X, Li J, Wang M-H, Ye Y-H. 2013. Antifungal screening of endophytic fungi from Ginkgo biloba for discovery of potent antiphytopathogenic fungicides. FEMS Microbiol Lett. 339(2):130-136.

Zulaika. 2014. Pemanfaatan cendawan endofit dalam pengendalian busuk umbi (Fusarium oxysporum) pada bawang merah (Allium cepa var. aggregatum). 